\title{
Backdated Stock Options Ownership Impact On The Corporation, Management, \& Shareholders
}

Karen T. Cascini, Sacred Heart University, USA

Alan DelFavero, Sacred Heart University, USA

\begin{abstract}
In the post-Sarbanes-Oxley Act (SOx) world, there has been an unprecedented crackdown on fraudulent activity occurring within corporate America. During recent years, many companies have granted stock options to their executives and employees as part of compensation packages. While the issuance of stock options as a component of compensation is considered to be a legal practice, corruption has taken this corporate resource to unlawful heights. Recently, numerous corporations have been in the news for potentially backdating stock options. Accordingly, the purpose of this paper is to distinguish between legal and illegal aspects of backdating stock options, and to examine the ethics of such corporate activity.
\end{abstract}

Keywords: accounting, stock options, backdating, corruption, greed, executive compensation, corporate scandals, accounting fraud, corporate negligence, business ethics, Sarbanes-Oxley Act, investor risk

\section{BACKGROUND}

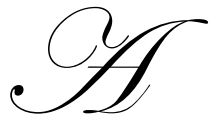

stock option grant is a type of warrant which "allows individuals to have the opportunity to purchase a predetermined number of shares of common stock at the exercise price (strike price), which is usually the price on the date of grant" (Bandler \& Forelle, 2006). The date which the individual obtains the option is considered to be the grant date (Kieso, WeyGandt, Warfield, 2005, pg. 781). If the company's common stock price rises above the strike price, these options can then be exercised and are considered to be "in the money." On the other hand, if the stock price fails to rise above the strike price, then the options are "underwater," translating into worthlessness. To be clear, the actual concept of backdating stock options is not illegal. Yet, this is only true if the process is performed correctly.

Backdating can only be rendered a legal practice if a company discloses, at the time of issuance, that the grant date may be later revised. However, if documents are altered to allow the option grant date to appear to be earlier than was actually the case, "this violates securities laws and is deemed illegal" (Conroy, Evans, Panikkath, Stettler, \& Saperia, 2006). In essence, when a corporation illegally backdates its stock options, it pretends that the grant date occurred much earlier than it was in actuality, which typically yields a drastically lower strike price (Bandler \& Forelle, 2006). Consequently, some executives are attracted due to the colossal profit potential. A summary of how stock options are issued and backdated is presented in Exhibit 1.

According to Fred Whittlsey, author of "The Governance Implications of Stock Options Backdating," the concept of backdating began in the 1990s when Micrel Incorporated, a technology company, issued newly hired employees stock options using "the preceding 30-day low price" as part of their compensation packages. Subsequently, other companies learned of the practice and began to backdate as well (Whittlesey, 2006). However, many businesses determined that the act was unethical and stopped before creating substantial legal issues. 
What is a stock option?

\section{Exhibit 1: Stock Options \& Backdating Defined}

An opportunity to purchase a share of stock at a specified price, called the strike/exercise price, after/before a predetermined period of time lapses.

How is the strike price determined?

The strike price is equal to the per-share price the stock is trading at on the date the stock option is granted

When can a stock option be exercised?

After the "vesting" period has passed, but before the stipulated expiration date. Upon exercise, the market price must be greater than the strike price.

What is backdating?

Backdating occurs when corporate management retroactively alters the grant date, typically to when the stock traded at its minimum price for the year.

\section{Is backdating always illegal?}

No, but management must disclose at the time of grant that the strike price may be changed. The concept was pioneered by Micrel Inc., a technology company in

the mid-1990s. The strike prices of these options were equivalent to the lowest share price of the foregoing 30 day period

Which industries have been found guilty of backdating?

Technology, Communications/Security, Retail, Healthcare, Media, Biotechnology, Consumer Discretionary, \& Insurance

How does the justice system handle cases of illegal backdating?

Corporations may pay fines to the U.S. govt.; executives may be forced to resign, sentenced to prison, and/or relinquish their remaining stock options.

There are two types of processes which can be deemed similar to the illegal backdating of stock options. The first is spring-loading which occurs when a company intentionally plans to grant stock options immediately before upbeat news is announced. Conversely, bullet-dodging takes place when a company deliberately schedules to grant options after the expected release of poor news (Conroy, Evans, Panikkath, Stettler, \& Saperia, 2006). Nevertheless, academic and legal experts have not given a definitive answer in regards to the ethical implications that spring loading and bullet dodging may create. According to Christopher Cox, former SEC Chairman, "springloading is bound up with concepts of insider trading" (Shaw, 2006).

Other individuals, such as Fred Lipman, a lawyer from the law firm Blank Rome, suggested that "the practice of spring-loading is legal as long as the compensation committee awarding the options knows the same information as the recipient," and the company discloses the information to shareholders. However, Lipman said, 'if both sides didn't have equal knowledge, insider trading rules can be violated" (Shaw, 2006).

According to Marc Siegel, a CPA and author of "Options Backdating," in the October 2007, edition of the CPA Journal, based on the suggestions of academics, 29\% of stock option grants were backdated prior to the enactment of SOx. Based on a survey of 100 companies "with the greatest proforma options compensation in the pre-SOx era," conducted by The Center for Research and Analysis, on at least three occasions, $17 \%$ of these companies granted their stock options at "40-day stock price lows which were immediately followed by a significant stock increase." However, the mechanics of this practice have become much more transparent since the passage of SOx. Presently, a corporation must file a Form 4 with the SEC at a maximum of two days after issuing stock option grants (Siegel, 2007). Form 4 must be completed for all insider trading transactions.

According to Siegel, there are five risks involved with illegally backdating stock options. However, based on the opinion of the authors, the three primary risks are Securities \& Exchange Commission/Department of Justice (SEC/DOJ) risk, earnings restatement risk, and management credibility risk. In regards to SEC/DOJ risk, this typically proves to be very time consuming and costly if a formal investigation is launched. Second, earnings restatement risk may occur if the backdating of options is proven to be a reality. The corporation may be forced to restate earnings for past fiscal periods, which may threaten debt covenants and place downward pressure on the common stock price. Lastly, management risk transpires when shareholders lose respect for the management of the company, and as a consequence, the board of directors may be forced to eliminate the executives involved (Siegel, 2007). 
All of the above practices raise strong ethical and legal concerns. While the legalities of spring-loading and bullet-dodging continues to be debated, fraudulent backdating has been the primary concern of regulators in this regard. Many companies, once Wall-Street stars, have suffered greatly due to backdating scandals.

According to A Perfect Pay Day, devised by The Wall Street Journal, as of September 4, 2007, 140 companies have "disclosed government probes, misdated options, and/or had restatements and or/executive departures" directly due to backdating allegations. Nonetheless, some establishments might not be included in this figure if they announced the launch of an internal probe (Perfect Pay Day, 2007). Based on this data, approximately $37.9 \%$ of the investigations were started by the SEC; $37.1 \%$ were launched by both the SEC \& DOJ; $1.4 \%$ was solely launched by the DOJ; and $23.6 \%$ announced an internal investigation. A graphical representation is displayed in Figure 1.

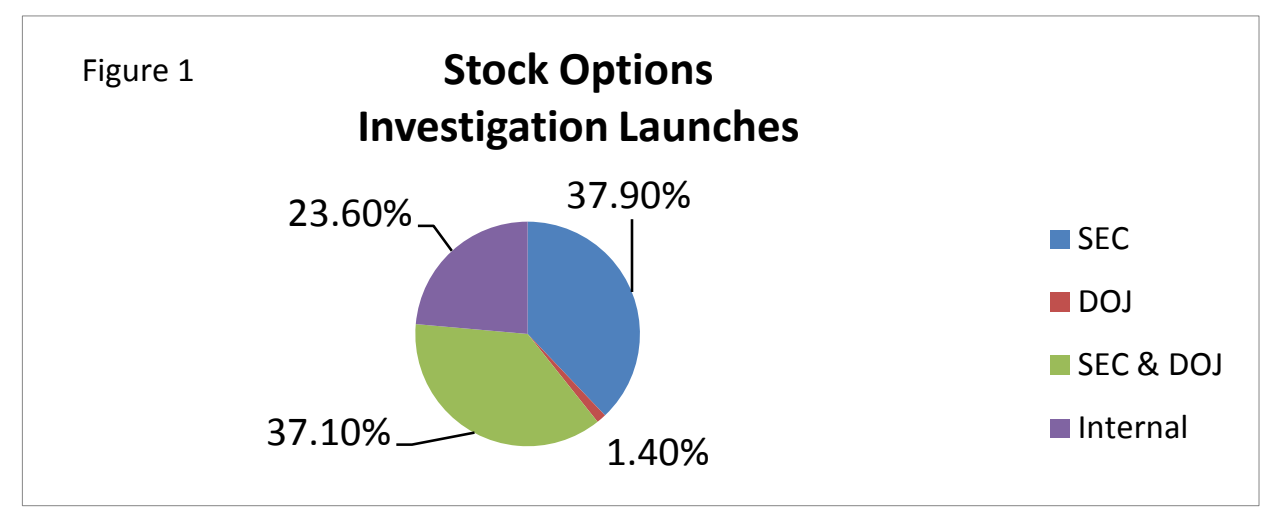

Additionally, it is important to determine which types of businesses are more likely to backdate. Based on the information presented in A Perfect Pay Day, it is evident that technology companies (software/hardware manufacturers, internet, and telecommunication/medical equipment producers) backdate the most frequently. Approximately $58.3 \%$ of the companies listed for backdating were technology related. This compares to $10.1 \%$ for communications and security organizations, $10.1 \%$ for organizations designated as "other" (which included financial firms, petroleum producers, and educational institutions), $6.5 \%$ for retailers, $5 \%$ for healthcare, $3.6 \%$ for media, and finally, biotechnology, medical/health, and insurance, ranked 2.2\% each (Perfect Pay Day, 2007). A graphical representation is illustrated in Figure 2.

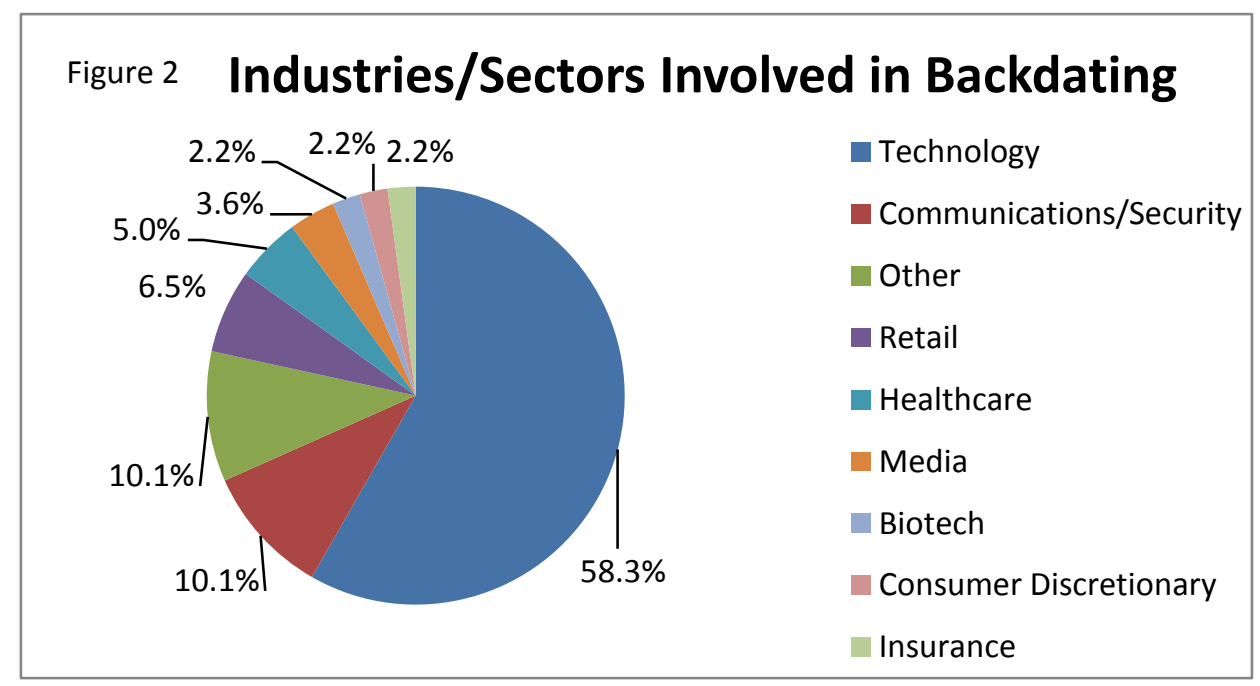


Throughout the paper, numerous backdating cases will be discussed. However, due to space constraints, only a fraction of the reported cases can be presented. Nonetheless, these examples will fairly represent the full magnitude of backdating scandals on the involved companies, their executives, and stakeholders.

\section{CORPORATE AMERICA INTERTWINED IN THE BACKDATING DEBACLE}

In the media, the largest companies suspected of backdating have received the greatest publicity. A summary table of the large companies discussed, along with costs associated with backdating and the penalties imposed by the SEC and/or DOJ, are displayed in Table 1. During 2006, one of the largest options backdating scandals involved UnitedHealth Care (UNH), and the company's former CEO, "Dr. William McGuire, who was forced to step down after the findings of an internal probe" (Bandler \& Forelle, 2006). Unlike many executives, "Dr. McGuire, a 260 pound, ambitious, six-foot-six man," did not begin his career in the business world. Before accepting the role as CEO of UNH in 1991, McGuire was a pulmonologist. Yet, in the beginning of the 1990s, as the "managed-care" industry was developing, McGuire, at the age of 42, became highly interested in the potential of this business. "He rapidly proved himself to possess the rarest of commodities: a physician with a gift for business" (Elkind, 2007).

During McGuire's tenure, through a combination of "smart deal making, making savvy investments in technology, and creating a visionary strategy," the company morphed into a "powerful force in American medicine." As a result, the common stock price rose over 5000\%, through October 2006 (Bandler \& Forelle, 2006). Throughout this time, investors enjoyed an average growth rate in profits of $30 \%$ per annum! Ultimately, the corporation developed into a $\$ 70$ billion large cap, in contrast to its 1991 market capitalization of $\$ 600$ million (Elkind, 2007). Yet, a great deal of these profits was created as a result of penny pinching. According to Dr. Jennifer Gobel, a pediatrician, "the company stated that they would not pay an extra $\$ 5$ for a nasal flu vaccine" (McCartney, 2006). Of course, any CEO that generates these types of returns would be admired by shareholders.

\begin{tabular}{|c|c|c|c|c|c|c|}
\hline \multirow{2}{*}{$\begin{array}{c}\text { Table } 1 \\
\text { Corporation }\end{array}$} & \multirow[b]{2}{*}{$\underline{\text { Years }}$} & \multicolumn{3}{|c|}{ Corporate Conglomerates Backdatin } & \multirow[b]{2}{*}{ Executive Penalty } & \multirow[b]{2}{*}{ Corporate } \\
\hline & & Assertion & Execuitve & Corp. & & \\
\hline & & & Guilty? & Guilty? & & $\underline{\text { Penalty }}$ \\
\hline UnitedHealth & 1994-2005 & CEO Backdated Millions of Options & Yes & Yes & $R \& R E \$ 620 \mathrm{~m} \& 3.7 \mathrm{~m}$ additional options & $\$ 2.395 \mathrm{~b}$ E\$ \\
\hline Home Depot & $1981-2000$ & Home Depot Routinely Backdated & No & Yes & $\mathbf{R}$ & $\$ 200 \mathrm{~m}$ E\$ \\
\hline \multirow[t]{2}{*}{ Apple } & 1997-2002 & Apple Regularly Backdated \& & No/Yes & Yes & CEO Acquitted; & \\
\hline & & CEO was Involved \& Aware & & & CFO RE $\$ 3.5 \mathrm{~m}$ options \& $\$ 150 \mathrm{k}$ & $\$ 84 m$ E\$ \\
\hline \multirow[t]{2}{*}{ Broadcom } & 1998-2003 & Founders backdated $232 \mathrm{~m}$ options & Yes & Yes & Executives face loss of options and & \\
\hline & & & & & ability to serve for any public company, $\$ 12 \mathrm{~m}$ fine & $\$ 2.22 \mathrm{~b} E \$ \& \$ 12 \mathrm{~m}$ \\
\hline \multirow[t]{2}{*}{ Research in Motion } & 1998-2006 & Executives backdated 3,000 options & Yes & No & $R, \$ 77 \mathrm{~m}$ fine, and executives banned & \\
\hline & & & & & from serving on board for up to 5 years & $\$ 250 \mathrm{~m}$ E\$ \\
\hline \multicolumn{7}{|l|}{ Abbreviations } \\
\hline \multicolumn{7}{|l|}{$R=$ Executive Resigned } \\
\hline \multicolumn{7}{|c|}{ RE= Relinquishment of a disclosed \# of options } \\
\hline \multicolumn{7}{|l|}{ NYD $=$ Not Yet Determined } \\
\hline ES=Earnings Restatement & & & & & & \\
\hline
\end{tabular}

The success of Dr. McGuire was commended by Wall-Street. Even though all corporate executives should realize at some point that their company's common stock price is fairly valued, McGuire argued that the corporation had become the "GE of healthcare," and that the equity markets would continually increase the share price's value. In a 2003 interview with Fortune Magazine, McGuire stated, "if you go to Silicon Valley, we're paupers. Another $50 \%$ could be added to the stock price" (Elkind, 2007). However, the rise in the stock price can be attributed to the drastic increase in profits, due to substantial cost cutting.

While the corporation began to grow through continuous acquisitions, accordingly, McGuire's compensation packages did as well. As early as 1999 , McGuire received over $\$ 49$ million from sales of stock besides $\$ 22$ million in options. "By the end of 2005, McGuire held so many options that a \$1 change in the stock 
price would yield a $\$ 30$ million change in his net value" (Elkind, 2007). McGuire's "cash out" commenced with his 2004 sale of $\$ 114.8$ million in stock options (Benko, 2006). By the end of 2005, he held over $\$ 1.78$ billion in options that had yet to be exercised (Elkind, 2007), but in 2006, \$137 million worth of options were cashed (Benko, 2006).

According to an October 2006 Wall Street Journal article, in April 2006, UNH announced the SEC's investigation into its stock options practices. Although the corporate spokesman asserted that all stock option issuances were "appropriate," McGuire placed senior executive pay (which also contained stock options) on hiatus (Bandler \& Forelle, 2006).

However, McGuire's preventative measures did not halt the enterprise's deterioration. In May 2006, UNH announced that "there was a "significant deficiency" in regards to its accounting for stock options grants. As a result, not only was UNH forced to restate earnings by a total of \$286 million for the prior three years, but was subpoenaed by the IRS and federal prosecutors. Consequently, the common stock price declined roughly $34 \%$ between December 2005 and May 2006, during the height of the scandal (Bandler \& Forelle, 2006).

The investigation, under the leadership of William McLucas of WilmerHale, "a former director of the enforcement division of the SEC," determined that, between 1994 and mid-2002, "eight of twenty-seven grants were either recorded at the second-to-lowest or third-to-lowest stock price of the quarter" (Bandler \& Forelle, 2006).

Accordingly, massive changes in corporate governance forced the CFO, Patrick Erlandson, in November 2006, and McGuire, in December 2006, to resign from their positions (Taub, July 2, 2008). Public speculation grew so substantially that McGuire and Erlandson controlled the purposeful backdating that, as a consequence, they both felt compelled to resign (Bandler \& Forelle, 2006). As a result, Stephen Hemsley, CPA, the enterprise's president and chief executive officer, assumed McGuire's role as CEO.

Yet, many challenges faced Hemsley. Not only did he have to contend with an ongoing investigation into the company's practices, but also a tarnished reputation of UNH. In response, Hemsley eliminated CEO stock options and "cut the board grants to directors in half" (Elkind, 2007), in an attempt to control the damage which occurred during the prior CEO's tenure (McCartney, 2006).

To be fair, McGuire was philanthropic in certain respects. In the Minneapolis/St. Paul, Minnesota area, in 2004 , he donated in excess of $\$ 10.7$ million to arts and educational organizations. Nonetheless, while these contributions may appear to be noble, McGuire was placed in a position to donate partly because of the profits derived from the backdated options. Additionally, "he will still receive $\$ 5.1$ million per year in retirement" (McCartney, 2006).

Ultimately, a reduction of both UNH's and Dr. McGuire's respective net worth resulted. In March 2007, UNH was forced to make a $\$ 1.5$ billion adjustment to earnings to financial statements for the years 1994 to 2005 . This correction was principally attributed to large "pre-tax errors in stock-based compensation" (Taub, January 2008). In December 2007, under the "clawback provision" of Section 304 of SOx (Taub, July 8, 2008), the SEC, DOJ, a UNH internal probe, and the legal system, forced the former executive to relinquish $\$ 420$ million worth of his options, in addition to the $\$ 200$ million he declared to surrender when he stepped down as CEO (Fuhrmans \& Lattman, 2007). Furthermore, McGuire was required to re-price many of these remaining options to higher share values along with disgorging \$7 million in criminal fines (Phelps, 2008). Nevertheless, McGuire still holds roughly $\$ 800$ million in unexercised options (Fuhrmans \& Lattman, 2007). However, the former CEO and his attorneys have continued to deny that he possessed any knowledge of the backdating. The attorneys contend that McGuire was "not an accountant and was therefore, not able to defraud investors, according to the Associated Press" (Harris $\&$ Taub, 2008).

Furthermore, the current CEO has been interrogated as well. As of June 2008, a class action shareholder lawsuit was filed in the Minneapolis U.S. District Court alleging that Hemsley was also deeply involved in the scandal. The corporation argues that the current CEO did not have any knowledge of the options backdating during the time in question. According to David Phelps, author of "Hemsley Had a Bigger Role in UNH Backdating," in 
1999, Hemsley received 500,000 stock options, which were "likely backdated." While Hemsley argues that he was unaware of this activity at the time, he has retroactively adjusted all stock option strike prices to the peak trading prices of all years in question (Phelps, 2008). Arguably, this appears to be a form of "reverse backdating," which may be too severe of a punishment, if an individual is proven to be innocent.

Subsequently, in July 2008, UNH settled one of its most significant backdating lawsuits. In an effort to resolve claims against it by the California Public Employees' Retirement System (CALPers), which held nearly 5 million shares of UNH's common stock, and Alaska Plumbing and Pipefitting Industry Pension Trust, in a class action lawsuit, the company agreed to disgorge $\$ 895$ million and revised "corporate governance and policies," in order to settle backdating charges. The corporation claims that this massive payment eradicates the possibility of "current directors and officers named in the lawsuit, and certain former officers and directors," along with UNH itself, being charged more extensively. Additionally, UNH agreed to pay \$17 million into a "settlement fund for the benefit of class members" to end claims from the Employee Retirement Income Security Act (ERISA), and the likelihood of any future legal action. (Taub, July 2, 2008). According to a UNH spokesman, the CALPers and ERISA settlements "provided closure and allowed the company to "focus on quality, affordable healthcare solutions" (Lifsher, 2008). Subsequently, Dr. McGuire was forced to return roughly 3.68 million unexercised stock options to the UNH as a result of this lawsuit settlement.

Though these lawsuits appear to have had severe repercussions for the company, a resolution is beginning to take form. Skepticism of the company's executives is starting to diminish. In February 2009, Hemsley was able to exercise over $\$ 98$ million of his own stock options, which were originally issued in 1999. These stock options' strike prices were reset to the highest price the company's common stock sold for in 1999 (Fuhrmans, 2009). Nevertheless, while the intense public scrutiny of UNH is beginning to wane in the post-McGuire era, it will still take many years to repair the public's perception of the company. A timeline of the UNH scandal is presented in Exhibit 2.

\begin{tabular}{|c|c|}
\hline & Exhibit 2: UnitedHealthCare Timeline \\
\hline 1991 & Dr. William McGuire becomes CEO of UnitedHealthCare (UNH), an enterprise with a market capitalization of $\$ 600 \mathrm{~m}$ \\
\hline 1994 & Backdating stock option grants commenced \\
\hline 1999 & McGuire starts accumulating stock options \\
\hline 2002 & The Sarbanes-Oxley Act was passed and enacted by Congress \\
\hline 2003 & McGuire proclaims in a Fortune Magazine interview that UNH is the GE of Healthcare \\
\hline Dec 2005 & Common stock price and market capitalization peak at $\$ 63$ and $\$ 70$ Billion, respectively \\
\hline Apr 2006 & UNH announces a SEC probe into their stock option practices \\
\hline May 2006 & A "significant deficiency" in accounting for stock option grants was announced. UNH restates earnings by $\$ 286 \mathrm{~m}$. \\
\hline Dec 2006 & $\begin{array}{l}\text { McGuire resigns and relinquishes } \$ 200 \mathrm{~m} \text { of stock options. Stephen Hemsley, President \& Chief Operating Officer, } \\
\text { assumes role as CEO }\end{array}$ \\
\hline Mar 2007 & A $\$ 1.5 B$ cumulative earnings adjustment for the years $1994-2005$ \\
\hline Dec 2007 & Ex-CEO surrenders an additional $\$ 420 \mathrm{~m}$ of stock options \\
\hline July 2008 & UNH disgorges $\$ 895 \mathrm{~m}$ in penalties to Alaska Plumbing and Pipefitting Industry Pension Trust \& CALPers in class action lawsuit \\
\hline Feb 2009 & Hemsley allowed to exercise $\$ 98 \mathrm{~m}$ of his own options \\
\hline Mar 2009 & UNH's common stock price falls to $\$ 15$ \\
\hline
\end{tabular}

However, UNH is not the only large profile company caught in the stock options backdating crossfire. Between 1981 and 2000, retailing giant Home Depot did not record approximately \$200 million of expenses pertaining to backdating. Although no evidence existed to prove that there was any illegal backdating occurring during the reign of the former CEO, Robert Nardelli (2000-2007), "a probe discovered that the stated grant date for stock options was "routinely earlier than the actual date on which the grants were approved" (Ward, 2006). However, due to poor stock performance and a scandalously large pay package, Nardelli stepped down on January 2 , 2007. Yet, the former executive will still receive a $\$ 210$ million severance package, which includes stock options and other forms of payment (Kavilanz, 2007). Though the impact on Home Depot's financial statements was not material, deception was still present.

Next, between 1997 and 2002, Apple admitted that it had backdated stock options grants to not only employees, but, the company's infamous CEO, Steve Jobs (Wolverton, 2007). Though the corporation indicated that 
he did not personally benefit from the options, even more problematic was the fact that that Jobs was "aware of or recommended' favorable grant dates" to the technology giant's workforce (Marmamo \& Weinstein, 2007). Nonetheless, the main arguments of numerous technology companies were that the backdating of options was technically legal, and the act was only used as a "valuable recruitment and compensation tool" (Quinn, 2007).

According to a Los Angeles Times article written by Dawn Chmielewski, "in August 1997, Apple handed four top executives options to buy a total of nearly one million shares. The next day, the value of those options jumped a staggering $48 \%$, or $\$ 7.7$ million." A lawsuit filed in December 2006, presumed that Apple had "springloaded options in advance of good news and 'backdated' other grants to days when the stock traded at low prices." Though an internal probe acquitted Jobs of any criminal misconduct, the company made it known to the SEC that between 1997 and 2002, 6,428 backdating incidents occurred (Chmielswski, 2007).

Consequently, Apple "took an $\$ 84$ million charge to correct its accounting." Additionally, the former CFO, Fredrick Anderson, who was accused of submitting financial statements, deemed to be inaccurate with his clear knowledge, agreed to relinquish $\$ 3.5$ million in stock options, in addition to $\$ 150,000$ in fines (Quinn, 2007). In regards to the company itself, shareholders sued, claiming that the issuance of stock options had eroded the value of the common stock price. However, the investors could not prove that the stock options caused a profound decrease in the common stock price as a result of dilution. Consequently, U.S District Judge Jeremy Fogel dismissed the claims (Taub, November 2007).

In another case, in May 2006, the SEC launched a probe into Broadcom, a manufacturer of semiconductors, based on the suspicion that the company had also altered its stock option grant dates. In July 2006, Broadcom announced that revenue and earnings for fiscal years 2000-05 would need to be restated due to the fact that in excess of $\$ 750$ million in non-cash based stock compensation expense was not recorded (Hechinger, 2006). Additionally, revenue had been artificially inflated by $\$ 1.5$ billion during fiscal years 1998-2003 (Gittelsohn, 2007). Broadcom has only been a publicly traded company since 1998! The technology giant acknowledged that approximately 8.5 million options were issued on May 26, 2000, at the lowest point for the encompassing three month period. The granting of these options was not conducted until several months later, however (Hechinger, 2006).

During December 2006, it was made public knowledge that three Broadcom executives profited by approximately $\$ 37$ million, in total, from the backdating scheme (Lansner, 2006). These executives were later determined to be David Dull, senior vice president and general counsel, Bruce Kiddoo, vice president and acting $\mathrm{CFO}$, and Thomas Lagatta, senior vice president for worldwide sales. In response to the corruption, Broadcom altered the grant dates of these options, thus, reducing their values (Gittelsohn, 2007).

As the case progressed, in January 2007, the company announced that its founders, Henry Nicholas (who left in 2003) and Henry Samueli, were highly involved in the scandal. At the time, the corporation determined that the backdating transpired between 1998 and 2003, and the expected charges had climbed to $\$ 2.22$ billion, drastically higher than the $\$ 750$ million originally foreseen (Granelli \& Reckard, 2007, \& Gittelsohn, 2008).

In April 2008, Broadcom settled with the SEC for $\$ 12$ million. However, the executives were not as fortunate. In May 2008, Samueli made the decision to resign from his post as Chairman, based on SEC allegations that he, along with Nicholas, had backdated a minimum of 88 times, which translated into a total of 232 million stock options (Christensen, Elliot, Reckard, 2008). In June 2008, Samueli admitted to authorities that he was indeed guilty for lying to prosecutors about his involvement in the backdating scandal. While a possible prison term has not yet been determined, Samueli agreed to pay federal prosecutors a fine of over $\$ 12$ million (Gittelsohn, October 15, 2008). In regards to Nicholas, while a trial had originally been set for April 2009, a Los Angeles federal judge, in February 2009, dropped Nicholas from the lawsuit based on an expiration of the five -year statute of limitations under California state law. Since Nicholas had resigned from Broadcom in 2003 and the lawsuit was not filed until 2008, Nicholas essentially became immune to any legal repercussions the company may face regardless of whether he was involved in the backdating scandal or not (Business Briefing, February 13, 2009).

The final large technology company involved in a stock options backdating scandal to be discussed is Ontario, Canada-based Research in Motion (RIMM). RIMM is well known as the maker of the wireless e-mail 
gadget, BlackBerry. In September 2006, as numerous stock options backdating scandals broke, RIMM launched an inquiry into its own methods for issuing stock options (Austen, 2006). Allegedly, the lawyers and auditors conducting the investigation found "incorrect dates on stock option grants" originally issued between 1998 and 2006 (Business Briefing, October 14, 2006). In total, over 3,000 stock options were deemed to have improper grant dates (Vascellaro, 2007).

In March 2007, it was announced that the company would need to restate earnings and reduce overall profits by as much as $\$ 250$ million in total for 1998 through 2006 as a result of the scandal. Although the investigation did not determine that all of the stock options were backdated, it was obvious that, on many occasions, the stock options grant dates "preceded a run-up in RIMM's share price." The company's former chairman and coCEO, Jim Balsillie, suggested that the reasons why the stock options may have had improper grant dates was due to the fact that the company grew too rapidly for anyone to notice the errors. During RIMM's early years, Balsillie was the approver of stock options grants. According to Balsillie, "RIMM was in the habit of pricing options from the date an employee verbally agreed to join the company." Although this act was later proven to violate U.S. securities laws, Balsillie stated that he was unaware that this method could defy U.S. law and that all of the mistakes made by the company were done inadvertently (Vascellaro, 2007).

As a result of the above allegations, the SEC and the Ontario SEC launched an investigation into the company's stock options issuance practices. In addition, a class action lawsuit was filed by the Ironworkers Ontario Pension Fund which held shares in RIMM, as the investigation uncovered proof that "executives and independent board members received backdated options" (Gray, 2007).

In March 2007, Balsillie agreed to resign from his position as chairman. In addition, Balsillie and Michael Lazaridis, co-CEO, "agreed to pay about $\$ 4.25$ million each to 'assist RIMM in defraying costs from the board probe and the earnings restatement" (Vascellaro, 2007). The final ruling on the backdating scandal, however, did not occur until February 2009. At this time, four RIMM executives agreed to pay roughly U.S.\$75 million in fines to Canadian regulators. Balsillie, who is still co-CEO, stated that he would also step down from RIMM's board of directors for a period of 12 months, in addition to being banned from serving on the board of any company during that period (Weinberg \& Silver, 2009). The other three executives disgorging funds were Lazardis, Dennis Kavelman, RIMM's former finance chief, and Angelo Loberto, former VP of Finance (Shwiff, 2009). With regard to fines imposed by U.S. regulators, RIMM announced in mid-February 2009 that the four former executives "will pay about $\$ 2.3$ million [in total] to settle U.S. SEC charges related to the stock-option backdating." The SEC banned Loberto and Kavelman from "serving as officers or directors of any company issuing securities registered with the SEC" for a period of five years as well (Shwiff, 2009). While the company and the executives argued that the backdating was unintentional, the punishment for such acts, whether derived from fraud or negligence, results in a severe punishment.

Clearly, large, well-known corporations whose executives are found guilty of backdating are punished for their actions either by the government in which the company is headquartered and registered to be publicly traded, the enterprise's board of directors, shareholders, and/or in the eyes of the public. However, while the corporate titans have typically received the most coverage in the press, there is a plethora of smaller and midsized companies who have also been found guilty of backdating stock options.

\section{IT'S NOT JUST CORPORATE TITANS: SMALLER CORPORATIONS ALSO BACKDATE}

Less obvious organizations have also been caught in the backdating corruption ring as well. A summary is presented in Table 2. First, Andrew McKelvey, the former CEO of Monster Worldwide, Inc., the job search agency, was accused of backdating employee stock option grants throughout a seven-year period. Between 1996 and 2003, the CEO had misrepresented employee compensation expenses, thus exaggerating earnings by approximately $\$ 300$ million. McKelvey confessed that he was aware of the backdating and the misleading costs, and did sign off on the faulty statements, but did not receive any backdated options (Taub, January 2008). 


\begin{tabular}{|c|c|c|c|c|c|c|}
\hline \multirow{2}{*}{$\begin{array}{c}\text { Table } 2 \\
\text { Corporation } \\
\end{array}$} & \multirow[b]{2}{*}{$\underline{\text { Years }}$} & \multicolumn{4}{|c|}{ Smaller Corporations Backdating } & \multirow[b]{2}{*}{ Corporate } \\
\hline & & Assertion & Execuitve & Corp. & Executive Penalty & \\
\hline & & & Guilty? & Guilty? & & Penalty \\
\hline Monster & 1996-2003 & CEO Backdated \& Received $\$ 23 \mathrm{~m}$ & Yes & Yes & CEO: $R \& \& 8.27 \mathrm{~m}$ fine; CFO: NYD & $\$ 340 m$ E $\$ \$ 48 m$ ruling \\
\hline \multirow[t]{2}{*}{ SafeNet } & $2000-06$ & Executives Did Not Adequately & & & & \\
\hline & & Record Compenation Expenses & Yes & Yes & $\$ 1 \mathrm{~m}$ fine \& Six-Month Imprisonme & $\$ 14 \mathrm{~m} E \$$ \\
\hline Cablevision & 1997-2002 & Backdated For 16 Executives & Yes & Yes & Aggregate Fine of $\$ 34.4$ million & $\$ 89 \mathrm{~m}$ E\$ \\
\hline Tyson & 2001-03 & Organization Springloaded & Yes & No & $\$ 4.5 \mathrm{~m}$ Fine & N/A \\
\hline \multicolumn{7}{|l|}{ Abbreviations } \\
\hline \multicolumn{7}{|c|}{$R=$ Executive Resigned } \\
\hline \multicolumn{7}{|c|}{$\mathrm{RE}=$ Relinqiushment of a disclosed \# of options } \\
\hline$E \$=$ Earnings Rest & atement & & & & & \\
\hline
\end{tabular}

While federal regulators did not fully prosecute McKelvey because of a life-threatening disease, the SEC did charge him with "one count of conspiracy to commit securities fraud, falsifying statements to both the SEC and the auditors, and falsifying corporate books and records" (Taub, January 2008) In January 2008, the SEC ordered McKelvey to pay $\$ 275,990$ in fines. Additionally, he could no longer serve as "an officer or director of a public company" (CNNMoney, 2008) and was ordered to pay roughly $\$ 8$ million in penalties to Monster. However, in November 2008, McKelvey lost his battle with his illness and passed away at the age of 74 (Lohr, 2008). Former President, James Treacy, and the ex-controller, Anthony Bonica, were also charged for their involvement. The SEC indicted Bonica for "securities fraud and conspiracy in connection to the backdating of millions of dollars worth of employee stock option grants" (Taub, April 2008).

On the other hand, Treacy, who has argued that he has been completely innocent, was charged for his dishonesty to the organization's external audit committee. Apparently, the former president not only misrepresented the facts regarding the corporation's method for issuing stock options to the auditors, but profited by collecting in excess of $\$ 23$ million from the exercise of nearly 750,000 options. In addition, Sections 302 and 404 of SOx were violated through the validation by the executives that the faulty financial statements fairly represented economic reality (Taub, April 2008). In May 2008, Treacy was "charged by federal prosecutors with securities fraud and conspiracy in connection with the backdating of stock options." Allegedly, in excess of 58\% of Treacy's gains from the exercise of stock options were due to altering the grant date for these options retroactively to a more lucrative strike price (Maremont \& Kingsbury, 2008). Myron Olesnyckyj, Monster's ex-General Counsel, has also had criminal charges filed against him, but he has pleaded guilty and has been cooperating with regulators (Glovin \& Scheer, 2008).

In regards to Monster Worldwide, in late-2006, the company adjusted prior period earnings by roughly $\$ 340$ million to account for the unrecorded stock option expenses. In addition, a class action lawsuit, initiated by the Massachusetts-based Middlesex County Retirement System, was settled in August 2008. Monster agreed to pay Middlesex about \$48 million. The Middlesex Pension Fund had purchased shares in Monster's common stock and argued that the fraudulent backdating led to a significant devaluation of the investment (Campbell, 2008).

In another case involving a smaller company, SafeNet, an information security provider based in Maryland, in May 2006, "received a subpoena from the U.S. Attorney General's Office" (Taub, October 2006). At the time, the company "specialized in developing encryption technology to protect data for commercial clients, such as Bank of America and Nokia, as well as government customers including the Defense and Homeland Security Departments" (Witte, 2006). SafeNet admitted that it had backdated for employees, directors, and officers, from 2000 until 2006.

As a consequence, the company's earnings were overstated by a cumulative $\$ 14$ million (Bishop, 2008). SafeNet was forced to restate earnings for all of those years, and the CEO, Anthony Caputo, and CFO, Carole Argo, voluntarily resigned (Taub, October 2006). Yet, even more problematic for the company was that it faced default on 
$\$ 250$ million in debt due to the postponement of the filing of its second quarter 2006 financial reports because of the SEC investigation (Witte, 2006).

Partly as a result of the plunge in the company's stock price, Vector Capital, which focuses on taking technology companies private, acquired SafeNet for \$634 million, in March 2007 (SafeNet, Wall Street Journal, 2007). However, while shareholders may have been able to put the scandal behind them as a result of the acquisition, Argo was less fortunate.

According to Stephen Taub, author of "SafeNet's Ex-CFO Pleads Guilty to Backdating," based on the accusations of the SEC and the U.S Attorney General's Office, Argo, along with others, "reaped substantial benefits" by "engaging in a scheme to deceive SafeNet's board of directors, shareholders, auditors, and regulators by backdating stock option grants [occurring eight separate times] and not adequately recording or reporting the compensation expenses related to the grants" (Taub, October 2007). Argo, a mother of three, pleaded guilty to these charges in October 2007 and was ordered to pay a penalty equal to $\$ 1$ million, in addition to serving a six month prison sentence, in spite of the fact that she has been known to be a charitable person (Bishop, 2008).

Next, Cablevision Systems Corporation, in August 2006, admitted to backdating stock option grants between 1997 and 2002. Allegedly, the stock prices recorded on the grant dates did not correspond to the actual prices on those days (McCann and Taub, 2008). Accordingly, sixteen current and former executives, including a compensation consultant, were forced to relinquish a total of $\$ 34.4$ million in an effort to settle a lawsuit against the corporation (Harrington, 2008). The chairman, Charles Dolan, and the Chief Executive, James Dolan, were forced to repay \$1 million and \$1.37 million, respectively (McCann and Taub, 2008). Consequently, earnings between 1997 and 2002 were restated by a total of $\$ 89$ million (Associated Press, 2006).

Though this case contains the same characteristics as other backdating scandals, there were two attributes which differed significantly. According to Stephen Taub, author of, "Compensation Consultant to Pay for Backdating," the Cablevision case is "the first to involve a compensation consultant." The consultant, Harvey Benson, the CEO of Lyons, Benson, \& Co., must pay the corporation a total of "\$2 million over [a three year period] at a 6-percent annual interest rate," in addition to losing a one-time $\$ 1.5$ million payment upon completion of his consulting contract. Secondly, based on assertions brought forth by a derivative lawsuit, the company allegedly issued stock options to an executive after his death, and backdated to a time when the executive was alive (McCann and Taub, 2008). According to the Wall Street Journal, the executive, Vice Chairman Marc Lustgarten, passed away in 1999. The intent of issuing options to a deceased individual was to allow for Lustgarten's estate to exercise the options at a lucrative time (Associated Press, 2006). Although, the effects on Cablevision appeared to be immaterial, their practices were highly unethical, especially when taking into account that stock option grants were awarded to a departed executive.

The final case of smaller companies involved is Tyson Foods. Plaintiffs asserted that the company had spring loaded options at least three days before the release of favorable news. On August 15, 2007, "Chancellor William B. Chandler III ruled that Tyson's board had acted with 'disloyalty that could not have arisen from a good faith business judgment' in its position on spring-loading the options” (Harris, 2008).

Chancellor Chandler investigated three separate instances during 2001-2003 when the options were believed to have been spring-loaded. He claimed that, "compared to backdating, spring loading entails "much more subtle deception." The chief issue here is that Tyson chose to issue these stock options at a time when it personally benefited executives. However, stakeholders were not informed about the positive news releases regarding the company ahead of time (Flores \& Quigley, 2008). Therefore, the executives were given an unfair advantage. Consequently, in an effort to prevent the lawsuit from developing into a trial, the former CEO, Don Tyson and "a partnership that owns Tyson Foods shares, agreed to pay \$4.5 million to settle” (Harris, 2008)

\section{CALLOUS CORRUPTION}

While the companies presented above may appear to have abused the law, the following topic involves unthinkable corruption. September 11, 2001, was one of the most tragic days in American History. As a result of 
the terrorist attacks, the financial markets collapsed, resulting in the S\&P 500 declining by nearly $10 \%$ in the first week of trading after 9/11, along with the Dow Jones Industrial Average declining by 14\%, which had been "the worst full week of trading since Germany invaded France in May 1940" until the 2008-09 credit crisis (Bandler, Forelle, Maremont, 2007). The markets were very volatile during the following weeks.

While most Americans were grieving, some corporate executives had other ideas. According to Mark Maremont, Charles Forelle, and James Bandler, authors of "Companies Say Backdating Used in Days After 9/11," printed in the March 7, 2007, edition of the Wall Street Journal, companies such as KLA-Tencor, Affiliated Computer Services, Take-Two Interactive Software, Inc, and Progress Software Corporation were accused of altering stock option grant dates to the lowest stock price during the post-9/11 period. For instance, KLA-Tencor issued stock options to "at least 11 top executives on October 12, 2001, at the very bottom of a sharp dip in the company's stock price." Some of the companies acknowledged that they had purposely backdated to profit off of the low prices in the post-9/11 period. In comparison to prior years, backdating activity "more than doubled in lateSeptember 2001" (Bandler, Forelle, Maremont, 2007). A graphical representation is illustrated in Figure 3.

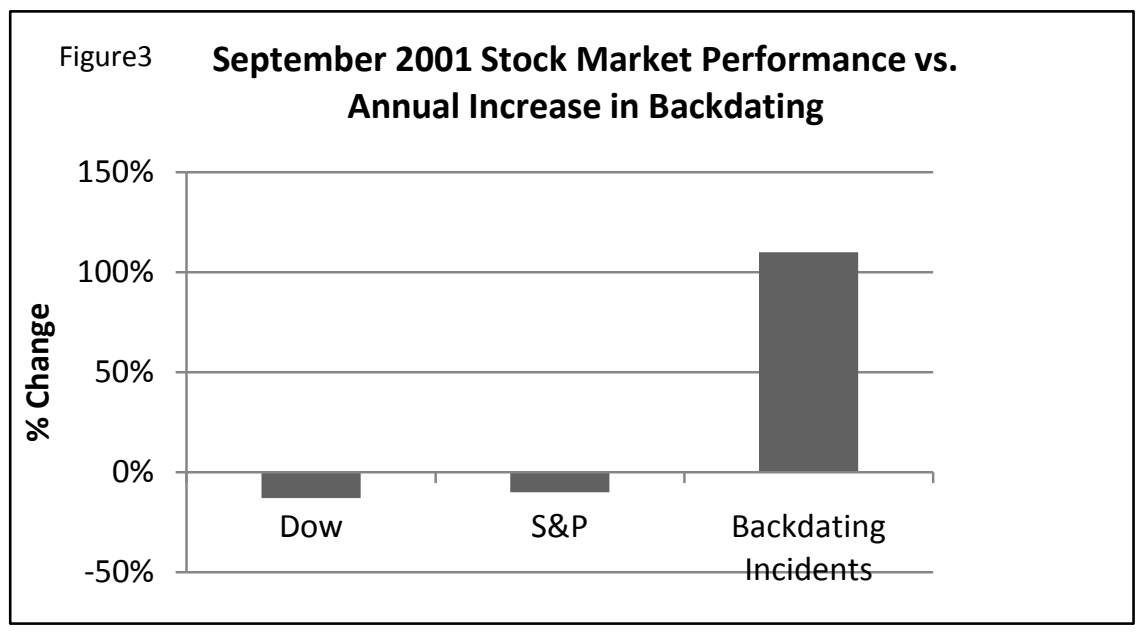

Regardless of whether these executives meant to issue stock options during this time, it appears suspect that the grant dates were retroactively set to the lowest price of the year. KLA-Tencor has taken action through firing the CEO and stripped him of all of his stock options (Bandler, Forelle, Maremont, 2007).

\section{THE INNOCENT CAUGHT IN THE BACKDATING CROSSFIRE}

While the main focus of this paper has been on the executives and corporations that have intentionally deceived investors, there are quite a few companies that have unintentionally backdated. Since the passing of SOx, every company suspected of such an activity has received negative publicity. For instance, Children's Place, in 2005, announced that it had found that 355,000 shares had been issued to four executives on April 29, 2005. However, Form 4 had not been submitted to the SEC until May 20, 2005, which was in violation of the new SOx rules. Though the stock price climbed nearly $50 \%$ in the weeks after the April $29^{\text {th }}$ grant date, the actual grant price was slightly higher than the lowest price (Rapoport, 2006). An internal probe determined that these instances were merely errors, and any form of "backdating" did not occur deliberately. Nevertheless, in January 2007, investors filed a class action lawsuit against the company (Ruth, 2007).

Second, Hansen Natural, a California based beverage producer, in late 2006, missed the deadline for the submission of Form 4 to the SEC even though the corporation issued stock options to insiders. Ultimately, this raised suspicion that the beverage producer may have intentionally backdated (Poletti, 2006). Between November and December 2006, four law firms launched class action lawsuits against the company. The Law Offices of Howard G. Smith, a Pennsylvania firm, asserted that Hansen "violated federal securities laws by issuing material 
misrepresentations to the market concerning, among other things, the company's improper backdating of stock option grants to certain key executives, thereby inflating the price of Hansen securities" (The Business Press, 2006).

In May 2007, a shareholder, Eli Alama, filed a lawsuit against the company claiming that the CEO and President, "misrepresented financial results and diverted 'hundreds of millions of dollars' of corporate assets to themselves by manipulating the grant dates on options." Nevertheless, as of May 14, 2007, the company announced that it had "unintentionally" overstated earnings by approximately $\$ 1$ million, between 2001 and 2005 (Los Angeles Times, 2007). Subsequently, in June 2007, a special committee determined that purposeful misconduct or backdating was not present. In August 2007, the SEC dropped the charges against the company (Perfect Pay Day, 2007).

Lastly, Home Depot, as previously discussed, was ordered to pay fines, and the CEO, Robert Nardelli, also was caught in the scandal even though he was not aware of nor did personally benefit from the backdated options. Yet, because the scandal launched a spotlight on the retailer, his pay package was brought to the public's attention. Consequently, he stepped down from his position as CEO. Backdating has had profound effects not only on a company, but all individuals involved by mere association.

Nevertheless, the above cases represent an unraveling of trust in corporate America. Years ago, an occurrence such as this would have not been brought to the attention of the SEC \& DOJ as easily. Yet, the scrutiny has been intensifying along with the number of scandals reported. SOx appears to have been effective in not only finding executives who stand to profit off of the tragic events of 9/11, but has also located the infinitesimal details of the accounting practices of even the smallest public companies.

\section{BACKDATING'S FUTURE}

While numerous investigations into corporate stock option practices by the SEC are continuing, inquiries into subprime lending activities appear to have started to take more precedence. According to Mark Schonfield, director of the Northeast Regional Office of the SEC in New York, "the subprime mortgage meltdown has generated another major area of activity for the SEC" (Gonzalez, 2008).

According to Holman Jenkins, author of "One Last Backdating Whipping Boy," published in the April 30, 2008 edition of the Wall Street Journal, "one beneficiary of the subprime hurricane has been the legion of corporate backdating miscreants [(wrongdoers)] whose travails have been blown off the front pages" (Jenkins, 2008). As the economy has deteriorated, the government has started to lose its concentration on backdating violations. For instance, according to Jenkins, the majority of the cases have not reached the intensity which would have been expected when the scandals were first reported. Based on the findings of Stephen Taub, the average backdating class action lawsuit has only amounted to $43 \%$ of the original projections set by the NERA, a global economic consulting firm (Taub, May 2008).

The authors believe that this poses a significant risk. The subprime crisis is yet additional proof of unethical activity occurring through lending to individuals who were never qualified to receive borrowed funds. However, subprime is not the focus of this paper. Nevertheless, as investigations blossom, if the SEC begins to concentrate less on backdating, the risk remains that some executives may yet again be enticed to alter stock option grant dates, believing that the practice will go unnoticed.

\section{CONCLUSION}

Based on the research, backdating appears to be conducted for numerous reasons. In certain situations, the practice is not considered illegal, as with Children's Place and Hansen Natural. Nonetheless, a great deal of scrutiny has been placed on the companies involved. In accordance with Siegel's risks, all of these organizations faced SEC/DOJ risk, earnings restatement risk, and management credibility risk. In each case, the SEC and/or DOJ launched an investigation into the accounting practices of each of these companies, with the exception of Children's Place. 
Second, each corporation was forced to restate earnings for the fiscal years affected. This reduced the validity of the financial data presented in previous years, thus, in many cases, spawning shareholder class action lawsuits. Lastly, management credibility risk is evident in each situation. However, the magnitude of this risk was much greater with some executives, compared to others. For instance, Dr. McGuire, a once well respected man, now has tarnished his reputation. With the exception of Apple's Steve Jobs, entangled executives were forced to resign. Even the slightest hint of backdating can impair an executive's good name.

In the opinion of the authors, there are other risks that should be addressed. The first is greed. While greed is not at all illegal, it has lead to the corruption of once reputable individuals. Life does not allow for a change of past decisions. Therefore, corporate executives do not have the right to retroactively change grant dates without disclosure at the time of the grant. The second is the risk to the executive's personal reputation. For instance, Carole Argo, CFO of SafeNet, was forced to spend six months in jail, though she had small children. While corporate managers such as these have attempted to reward themselves with artificial profits, they in fact caused severe disruptions to their personal life and families.

In conclusion, the authors believe that backdating should not be allowed, regardless of whether or not it is technically rendered legal. Springloading and bullet dodging, while not unlawful, certainly presents ethical complexities, as displayed in the cases presented above. The corporate risks of backdating stock options result in executives' losing their stock options, incurring enormous fines, and in many cases, resulting in criminal prosecution.

\section{AUTHOR INFORMATION}

Karen Cascini has been a professor of Accounting for eighteen years at the John F. Welch College of Business, Sacred Heart University in Fairfield, Connecticut. She teaches advanced accounting courses to undergraduate students and international accounting in the MBA program. Dr. Cascini received her Ph.D. from the University of Connecticut and is a licensed certified public accountant in the state of Connecticut. Her research interests include international and financial accounting and accounting ethics. She has traveled extensively presenting papers and teaching accounting topics to an international audience. She is widely published and her work appears in such journals as the Journal of International Financial Management and Accounting (JIFMA), The CPA Journal, The Journal of Business Case Studies to name a few. Dr. Cascini can be contacted at cascinik@ sacredheart.edu.

Alan DelFavero is currently an adjunct accounting instructor at the John F. Welch College of Business, Sacred Heart University in Fairfield, Connecticut. He teaches introductory financial and managerial accounting courses and intermediate accounting. A Monroe, Connecticut native, in 2006, DelFavero graduated summa cum laude from the Welch College of Business with a finance major and an accounting minor. While immediately pursing his MBA, he worked as Dr. Karen Cascini's graduate research assistant for the academic year 2007/08. DelFavero earned a gold medal, in 2008, for achieving a $3.97 \mathrm{GPA}$, the highest in his graduating class. He is also a member of three national honors societies.

\section{REFERENCES}

1. Associated Press. "Cablevision Gave Options to Dead Executive.” MSNBC.com September 22, 2006. http://www.msnbc.msn.com/id/14953199/ (accessed June 17, 2008).

2. Austen, Ian. "R.I.M. Says It's Reviewing Stock Option Practices." New York Times, September 29, 2006, pg. C11.

3. Bandler, James, Forelle, Charles, Maremont, Mark. "Companies Say Backdating Used In Days After 9/11." Wall Street Journal, March 7, 2007, pg. A1.

4. Bandler James and Forelle, Charles. "Embattled CEO To Step Down At United Health.” Wall Street Journal, October 16, 2006, pg. A1.

5. $\quad$ Benko, Laura. "UnitedHealth Sets off Waves" Modern Health Care 36, no. 17 (April 24, 2006): 12-13.

6. Bishop, Tricia. "SafeNet Judge Shows Pity: Former CFO Argo Gets 6-Month Term in Options Case." McClatchy-Tribute Business News, January 29, 2008. 
7. Business Briefing. "Nicholas Dropped from the Option Suit.” Los Angeles Times, February 13, 2009, pg. C4.

8. "Business Briefing." The Washington Post. October 14, 2006, pg. D2.

9. Campbell, Elizabeth. "Monster Agrees to $\$ 47.5 \mathrm{~m}$ Settlement." Boston Globe, August 2, 2008, pg. A7.

10. Chmielewski, Dawn. "At Apple, Timing Led to Overnight Windfalls." Los Angeles Times, January 3, 2007, pg A1.

11. Christensen, Kim, Elliot, Helene, \& Reckard, E. Scott. "Broadcom Founders Accused of Fraud." Los Angeles Times, May 15, 2008, pg. A1.

12. "Class-Action Firms Target Hansen." The Business Press, December 11, 2006, pg. 2.

13. CNNMoney.com, "Former Monster CEO to Pay for Stock Scheme." CNNMoney.com, January 23, 2008.

14. Conroy, Patrick, Evans, Matthew, Panikkath, Sunil, Stettler, Erik., Saperia, Nathan. "Options Backdating: A Primer." NERA Economic Consulting. October 5, 2006. http://www.nera.com/ image/PUB Backdating_Part 1_Primer_SEC1381 final.pdf, p. 9 (accessed September 7, 2007).

15. Elkind, Peter. "United Health and the Ghost of Dr. McGuire" Fortune, 155, no. 8 (April 30, 2007): 150.

16. Flores, Steven \& Quigley, Thomas. "Spring-Loading Options." The Corporate Counselor, May 14, 2008.

17. Fuhrmans, Vanessa "UnitedHealth CEO in Option Move" Wall Street Journal. February 11, 2009, pg. C2.

18. http://www.law.com/jsp/ihc/PubArticleIHC.jsp?id=1202421361008 (accessed June 8, 2008).

19. Fuhrmans, Vanessa \& Lattman, Peter. "UnitedHealth Ex-CEO's Pact Is Uncertain” Wall Street Journal, December 28, 2007, pg. A3.

20. Gittelsohn John. "Judge Delays Broadcom Co-Founder Samueli’s Sentencing.” McClatchy-Tribune Business News, October 15, 2008.

21. Gittelsohn, John. "Why the SEC Sued.” McClatchy-Tribune Business News, May 15, 2008.

22. Glovin, David \& Scheer, David. "Monster Ex-Officer Treacy Charged in Backdating Case." Bloomberg News, April 30, 2008, http://www.bloomberg.com/apps/news?pid=20601087\&sid=antCAs_Ti4Qk\& refer=home (accessed March 15, 2009).

23. Gonzalez, Gloria. "SEC to Remain Focused on Backdating, Subprime Investigations." Business Insurance 42, no. 7 (February 18, 2008): 31.

24. Granelli, James \& Reckard, E. Scott. "Broadcom Faults Founder in Probe." Los Angeles Times, January 24, 2007, pg. C1.

25. $\quad$ Gray, John. "Research in Trouble." Canadian Business 80, no. 6 (March 12, 2007): 9.

26. "Hansen Natural Sued by Investor." Los Angeles Times, May 25, 2007, p. C4.

27. Harrington, Mark. "Cablevision Agrees to Settle in Backdating Suits." McClatchy-Tribune Business News, June 5, 2008.

28. Harris, Roy \& Taub, Stephen. "Facing Backdating Claims: Pick Your Strategy." CFO Magazine, June 3, 2008.

29. Harris, Roy. “Tyson Foods Ducks Out.” CFO Magazine, January 31, 2008. http://www.cfo.com/printable/article.cfm/10556413/c_2984311?f=options (accessed January 23, 2008).

30. Hechinger, John. "Broadcom Faces at Least $\$ 750$ Million Charge to Correct Options Errors." Wall Street Journal, July 15, 2006, pg. A4.

31. Jenkins, Holman. "Business World: One Last Backdating Whipping Boy?" Wall Street Journal, April 30, 2008, pg. A15.

32. Kavilanz, Parija. "Nardelli out at Home Depot." CNNMoney.com, January 3, 2007. http://money.cnn.com/2007/01/03/news/companies/home_depot/index.htm (accessed September 15, 2007).

33. Kieso, Donald, Weygandt, Jerry, and Warfield, Terry. (2005) Intermediate Accounting. John Wiley \& Sons: New Jersey, pg. 781.

34. Lansner, Jonathan. "Ugly Options for Broadcom." Knight Ridder Tribune Business News, December 20, 2006, pg. 1.

35. Lifsher, Marc. “CALPers, Insurer Settle Case.” Los Angeles Times, July 3, 2008.

36. Lohr, Steve. “Andrew J. McKelvey, 74, Builder of Monster.com, Dies.” New York Times, November 28, 2008, p D8.

37. Maremont, Mark \& Kingsbury, Kevin. “Ex-President of Monster is Charged.” Wall Street Journal, May 1, 2008, pg. C3. 
38. McCann, David, and Taub, Stephen. "Compensation Consultant to Pay for Backdating." CFO Magazine, June 9, 2008.

39. Marmamo, Richard and Weinstein, Ryan. "Should Steve Jobs Go To Jail?" Wall Street Journal, January 10, 2007, pg A17.

40. McCartney, Jim. "McGuire's fall roils health care debate: UnitedHealth Stock Scandal Fallout Also Will Spill into Boardrooms, Local Arts." Knight Ridder Tribune Business News, October 17, 2006, pg. 1.

41. "Perfect Pay Day: Options Scorecard.” Wall Street Journal, September 4, 2007. http://online.wsj.com/public/resources /documents/info-optionsscore06-full.html, (accessed June 1, 2008).

42. Phelps, David. "Suit: Hemsley Had a Bigger Role in UNH Backdating." McClatchy-Tribute Business News, May 23, 2008.

43. Poletti, Therese. "Missed Deadlines Raise Possibility of More Backdated Options." Knight Ridder Tribune Business News, October 30. 2006.

44. Quinn, Michelle. "Apple Ex-CFO to Settle Claims.” The Los Angeles Times, April 24, 2007, pg. C1.

45. Rapoport, Michael. "Studying Children's Place Options: Unintentional Mistakes May Need Further Scrutiny As Delays Raise Questions.” Wall Street Journal, September 22, 2006, pg. C3.

46. Ruth, Joao-Pierre. "Skeletons in The Children's Place Closet." NJBIZ, no. 42 (October 8, 2007): pg 3.

47. "SafeNet Inc: Investors Agree to Buy Firm for \$634 Million.” Wall Street Journal, March 6, 2007, pg. A13

48. Shaw, Helen. "Is Spring-loading Wrong?" CFO Magazine, September 6, 2006, http://www.cfo.com/printable/art icle.cfm/7880157/c 2984338?f=options (accessed September 15, 2007).

49. $\quad$ Shwiff, Kathy. "RIM Officers Settle Charges.” Wall Street Journal, February 18, 2009, pg B7.

50. $\quad$ Siegel, Marc. “Options Backdating.” CPA Journal, 77, no. 10 (October 2007): 70-72.

51. Taub, Stephen. “A Monster Case of Backdating." CFO Magazine, January 23, 2008, http://www.cfo.com/article.cfm/10559786?f=search (accessed February 23, 2008).

52. Taub, Stephen. "Early Thaw Sought for Frozen Options." CFO Magazine, January 9, 2008.

53. Taub, Stephen. "Ex-Monster Controller Faces Backdating Charges." CFO Magazine, April 30, 2008, http://www.cfo.com/article.cfm/11289158/1/c_2984311?f=alerts. (accessed May, 22, 2008).

54. Taub, Stephen. "No Hard Feelings, SafeNet CFO, CEO Quit." CFO Magazine, October 16, 2006.

55. Taub, Stephen. "Options Probes Eye Two More Targets." CFO Magazine, May 19, 2006, http://www.cfo.com/article.cfm/6966432?f=search (accessed June 1, 2008).

56. Taub, Stephen. "SafeNet's Ex-CFO Pleads Guilty to Backdating." CFO Magazine, October 9, 2007.

57. Taub, Stephen. "Settling for Less? A Study in Backdating." CFO Magazine, May 15, 2008.

58. Taub, Stephen. "This Case is Closed, Mac." CFO Magazine, November 16, 2007.

59. Taub, Stephen. "UnitedHealth Settles Backdating Suit." CFO Magazine, July 2, 2008.

60. Vascellaro, Jessica. "RIM Sets Restatement, Shake-Up on Board in Backdating." Wall Street Journal, March 6, 2007, pg. A3.

61. Ward, Andrew. "Home Depot Probe Reveals Backdating Stock Options." Financial Times, December 6, 2006, pg. 19.

62. Weinberg, Stuart and Silver, Sara. "RIM Executives to Pay Big Fine on Options." Wall Street Journal, February 6, 2009, pg. B4.

63. Whittlesey, Fred. "The Governance Implications of Stock Option Backdating." The Corporate Governance Advisor 14, no. 5 (September/October 2006).

64. Witte, Griff. "SafeNet's Top Two Executives Resign After Stock Options Inquiry." Washington Post, October 6, 2006, pg. D4.

65. Wolverton, Troy. “Apple's Backdating Scandal.” Knight Ridder Tribune Business News, January 2, 2007. 
NOTES 